\title{
Genetic variations among white spot syndrome virus (WSSV) isolates from shrimp farms in Gujarat, north-west coast of India
}

\author{
PRASANNA KUMAR PATIL, HARESH G. SOLANKI*, SUBHENDU KUMAR OTTA, \\ KRISHNA PATEL*, P. SARAVANAN, GOPAL CHAVALI AND S. M. PILLAI \\ ICAR-Central Institute of Brackishwater Aquaculture, 75, Santhome High Road, Raja Annamalai Puram \\ Chennai - 600 028, Tamil Nadu, India \\ "Navsari Agriculture University, Navsari - 396 450, Gujarat, India \\ e-mail:pkpatilvet@yahoo.com
}

\begin{abstract}
The present paper documents the molecular diagnosis and genotyping of white spot syndrome virus (WSSV) isolates collected from different shrimp farms of Gujarat, north-west coast of India. Preliminary diagnosis was done using single tube PCR and genotyping of isolates by analysis of variable number tandem repeat sequence (VNTRS) in minisatellites viz., ORF 94, ORF 125, ORF 75 and ORF 75 flank. Out of the 79 samples analysed, 32 (33.80\%) were positive with low $(54.17 \%)$, medium $(8.33 \%)$ and high (37.50\%) severity of infection. Genotyping, using ORF 94 revealed that repeat units (RUs) 4 and 11 were the most frequent ones (32\%) while ORF 125 showed 5 different repeat types of which RU 5 was the most common (45.83\%). Two genotypes were observed for ORF 75, one showed multiple repeats of two 45 bp, followed by a $57 \mathrm{bp}$, whereas the other showed two repeats that included 5 and 4 repeats of $45 \mathrm{bp}$. Sequence analysis of the $54 \mathrm{bp}$ variable sequence of ORF 94 RU type 4 revealed single-nucleotide polymorphism (SNP) at $47^{\text {th }}$ base. Based on the results from ORF 94, dominance of RU types 11 or 4 were recorded for the first time in India and one sample showed 2 bands of different sizes indicating the prevalence of two different genotypes infecting the same pond at a given time. Further, no correlation could be observed between the virus genotype and the severity of the mortality in the outbreaks. The results suggest the widespread occurrence of WSSV in the region and circulation of distinct virus genotypes.
\end{abstract}

Keywords: Genotyping, Shrimp diseases, West coast of India, White spot syndrome virus

White spot syndrome virus (WSSV) affects commercially important species of penaeid shrimps under all age groups worldwide, including India (Karunasagar et al., 1997). In India, economic loss to the tune of $48,717 \mathrm{t}$ of shrimp valued at US\$ 1.85 billion was attributed to diseases (Kalaimani et al., 2013). The state of Gujarat has 3.76 lakh ha of potential brackishwater farming area concentrated mainly in the southern districts of Valsad, Navsari, Surat and Bharuch. Despite following the standard culture practices, losses due to WSSV continue to occur in the state. Information on the status of the disease in the shrimp farming regions is vital for developing suitable prevention and control strategies. Report on the incidence of WSSV and further characterisation has mostly been restricted to some of the southern Indian states like Andhra Pradesh, Tamil Nadu, Kerala and Karnataka (Otta et al., 1999; Vaseeharan et al., 2003; Pradeep et al., 2008; John et al., 2010) where large scale shrimp culture were practiced. However, such kind of information is not available from Gujarat where, major shrimp growing developed lately. The present paper documents the molecular diagnosis and genotyping of WSSV isolates based on the variable number tandem repeats (VNTRs) located in 3 minisatellites from shrimp culture operations in the state of Gujarat.

The study comprised shrimp samples submitted ( $n=79$ ) during April 2010 to Aug 2013 to Aquaculture Laboratory at Navsari Agricultural University (NAU), Navsari, Gujarat. PCR analysis for diagnosis of WSSV was done using commercial kit (Genei, Bangalore). All the DNA samples positive for WSSV were subjected to genotyping through variable number tandem repeat (VNTR) analysis by amplifying the 3 minisatellite regions, ORF 94, ORF 125, ORF 75 and ORF 75 flank using specific primers and cycling conditions (Pradeep et al., 2008). PCR amplicons of representative samples of ORF 94 and ORF 125 were cloned and sequenced to compare with available sequence information in the database while ORF 75 samples were sequenced to obtain the repeating patterns.

Of the total 79 samples used for diagnosis, 40.51\% were found to be positive for WSSV. Among the positive samples, the presence of either three $(941,525$ and 204 bps), two (525 and 204 bps) or one (204 bp) band 
indicated the degree of infection as strong, medium or weak based on the presence of copy numbers of WSSV DNA. Out of the total 32 positive samples, $54.17 \%$ samples were found with low, $8.33 \%$ with medium and $37.5 \%$ with high severity.

While genotyping, PCR for the 54 bp RU in ORF 94 revealed 5 repeat types which ranged from 4 to 11 RUs (Fig. 1) which was also verified by sequencing. Repeat type with 11 RUs was the most frequent one (32\%). Samples from Navsari, Surat, Baruch and Junagarh did not show any specific trend in their repeat types (Table 1). One sample showed 2 bands of different sizes indicating the prevalence of two different genotypes infecting the same

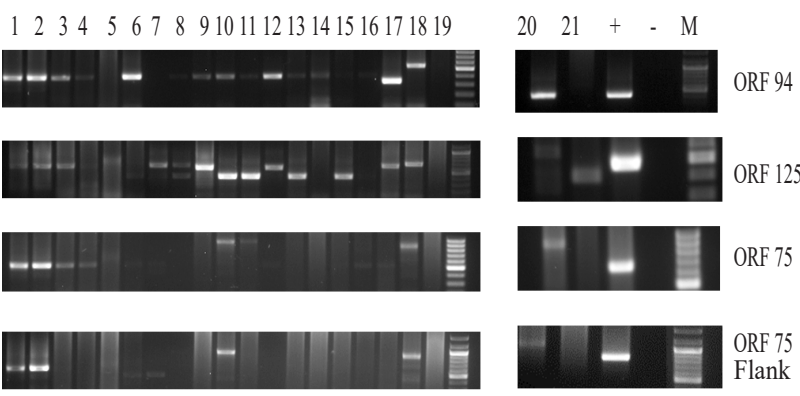

Fig. 1. Agarose gel showing PCR amplification product for ORF 94, ORF 125, ORF 75 and ORF 75 Flank Lanes 1 to 21: selected shrimp samples, Lane M : $100 \mathrm{bp}$ molecular weight marker, Lane +: positive control, Lane : negative control.
Variable number tandem repeats (VNTRs) associated with DNA minisatellites and the SNPs within these repeats are considered important for genotyping of WSSV isolates. The present report is based on three minisatellites ORF 75, 94 and 125. Application of these methods for typing WSSV isolates has been reported widely from the shrimp growing countries in the world (Dieu et al., 2004; Hoa et al., 2012; Gonzalez-Galaviz et al., 2013) while similar studies are limited from India (Musthaq et al., 2006; Pradeep et al., 2008; John et al., 2010) and the present study is the first report of WSSV genotyping from the state of Gujarat.

In the present study, typing based on ORF 94 showed highest number of RUs as 11 followed by 4 . Interestingly earlier reports from India showed highest prevalence of WSSV RU types 6 followed by 9 and 12 (John et al., 2010) and 7 followed by 2 and 8 (Pradeep et al., 2008). Similarly, highest prevalence of RU type 8 in Thailand (Wongteerasupaya et al., 2003) as well as 7 in Thailand (Kiatpathomchai et al., 2005), India (Pradeep et al., 2008), Vietnam (Hoa et al., 2005; 2012) and Mexico (Gonzalez Galaviz et al., 2013) were reported. On the contrary, in the present study, none of the samples showed the RU type 7. Dominance of WSSV RU types 11 or 4 indicates the circulation of separate genotypes in Gujarat against the reported dominance of types 6, 7 or 8 (Musthaq et al., 2006), 6 or 9 (John et al., 2010) and 7 or 2 (Pradeep et al., 2008) in southern India. Previous studies have reported the

Table 1. Number of samples positive for WSSV and the repeat units (RU) present in encoding ORF 94, ORF 125 and ORF 75 from Gujarat. ND $=$ Not detected

\begin{tabular}{|c|c|c|c|c|c|c|}
\hline \multirow{2}{*}{ Region } & \multicolumn{2}{|l|}{ ORF 94} & \multicolumn{2}{|l|}{ ORF 125} & \multicolumn{2}{|l|}{ ORF 75} \\
\hline & Amplicon size (bp) & RUs & Amplicon size (bp) & RUs & Amplicon size (bp) & RUs \\
\hline Valsad & 680 & 9 & 394 & 5 & ND & -- \\
\hline Navsarai & $400-750$ & $4-11$ & $337-557$ & $4-7$ & 850,896 & 1,2 \\
\hline Surat & 400,750 & 4,11 & $374-760$ & $5-10$ & 850,896 & 1,2 \\
\hline Baruch & ND & -- & 409 & 5 & ND & -- \\
\hline Junagarh & ND & -- & 409 & 5 & ND & -- \\
\hline
\end{tabular}

pond at a given time (Fig. 1, ORF 94 - lane 8). Sequencing of the $54 \mathrm{bp}$ PCR product from the representative 4 RU sample revealed single nucleotide polymorphism (SNP) at the $47^{\text {th }}$ base of the $3^{\text {rd }}$ repeat unit where $G$ is replaced with T. PCR for the 69 bp RU in ORF 125 showed 5 repeat types ranging from 4 to 10 RUs. Genotype with 5 RUs was the most common $(45.83 \%)$ with no sample showing two amplicons. Based on PCR amplification, two genotypes were observed for ORF 75. For the two different types of ORF 75 products that were sequenced, one of the isolate showed multiple repeats of two $45 \mathrm{bp}$ followed by a $57 \mathrm{bp}$, whereas the other variety included two of the repeats that included 5 and 4 repeats of 45 bp also.
SNP at $48^{\text {th }}$ base ( $G$ replaced with $T$ ) in the $54 \mathrm{bp}$ variable sequence in standard WSSV-Thailand, WSSV-Taiwan and WSSV-China and one from India (Pradeep et al., 2008). However, in the present study, replacement of $\mathrm{G}$ with $\mathrm{T}$ at $47^{\text {th }}$ position further support our observation on circulation of distinct WSSV genotype in the study area.

Similar to previous observations, mixed infection with two RU types, 4 and 11 was noticed in the present study (Hoa et al., 2005, 2011, 2012; Musthaq et al., 2006; Pradeep et al., 2008). In contrast to the earlier observation which correlated mixed infection with lower virulence (Hoa et al., 2012), in this case the farm with mixed WSSV infection had suffered the similar severity as that of single 
genotype infection. Further, dominance of the RU type 11 in WSSV outbreaks in the region of Gujarat is in contrast to the earlier observation that genotypes with less than 8 RUs dominate the outbreaks and genotypes with more than 11 RUs dominate in healthy ponds (Hoa et al., 2012). Previous studies have reported the association of WSSV genotype with virulence and correlated low RU numbers with virulence (Hoa et al., 2005; Waikhom et al., 2006; Pradeep et al., 2008). In contrast to previous observation of Hoa et al. (2012), in the present study no correlation could be observed between the genotype and the severity of mortality in the outbreaks, which might be due to the fact that samples analysed here were only from outbreaks and no sample from normal ponds was included. Similar to our observation, John et al. (2010) also could not establish the relation between genotypes and virulence even under experimental conditions.

Comparing the geographical distribution of different genotypes in Valsad, Navsari and Surat districts of Gujarat, a specific pattern was noticed in the 54 bp RU (Valsad and Surat are $150 \mathrm{~km}$ apart and Navsari is located halfway between Valsad in the south and Surat in the north). Isolates from Valsad showed RU type 9 only, while Surat samples showed 4 and 11 RU types. It is interesting to note that isolates from Navsari which is located between Valsad and Surat showed the RU types 4, 9 and 11. However, genotypes within the location were almost identical similar to earlier observations (Hoa et al., 2012) that circulation of distinct genotypes in small spatio-temporal scales.

Based on ORF 125, WSSV positive samples showed 5 genotypes (4-7 and 10) in the present study. Earlier studies have reported 5 RU genotypes (Dieu et al., 2004) and 14 RU genotypes (Hoa et al., 2012) from Vietnam while Indian studies reported RU genotypes varying between 2 to 14 (Pradeep et al., 2008). Major RU types reported earlier were 6 and 7 in Vietnam (Hoa et al., 2012). The domination of RU genotype 5 in Gujarat and RU 4 as major genotype from South India (Pradeep et al., 2008) suggest the circulation of different RU types in the region. It has been observed in the present study that, WSSV isolates having same repeat pattern in ORF 94 showed difference in ORF 125 and ORF 75. This variation was suggested to be due to variation in the sequences of these three microsatellites and hence the need to consider all the 3 minisatellite loci for epidemiological studies (Pradeep et al., 2008). However, in contrast to the previous observations (Dieu et al., 2004; Pradeep et al., 2008; Hoa et al., 2011, 2012), similar number of variations in the tandem repeats were observed in ORF 94 and ORF 125. Among the PCR positive samples, 10.34\% of the samples could not be amplified in each of the three
ORFs. This variation in amplification in genotyping was attributed to variations of sequences in the primer binding sites or the low levels of target DNA (Hossain et al., 2004; Pradeep et al., 2008). This was further confirmed in one of the sample which did not show amplification with standard primers for ORF 75 but showed the amplicon when ORF 75 flank primers were used. While the use of ORF 94 and ORF 125 has been proved to be useful in various epidemiological studies, the same for ORF 75 has so far not been advocated. This could be due to sequence variation at the primer binding sites contributing to difficulties in its detection. In the present study, many of our samples were not amplified either by ORF 75 or ORF 75 flank primers. At the same time, these were amplified by ORF 94 and ORF 125. Further refining of the primer design may be helpful in detecting this particular ORF.

It can be concluded from this study that WSSV is widespread in Gujarat which is a major shrimp growing state in the north-west coast of India. Genotyping of WSSV isolates based on RU patterns of VNTRs suggest that, some distinct genotypes of the virus are circulating in Gujarat and are distinct from the isolates reported from southern part of India and the other geographically distant shrimp growing regions like, Mexico, Thailand and Vietnam. Further in depth study of SNPs would help in tracking the movement of virus within the country.

\section{Acknowledgements}

Authors are thankful to the Director, ICAR-Central Institute of Brackishwater Aquaculture (ICAR-CIBA) and Vice Chancellor, Navsari Agriculture University (NAU) for the grants and facilities for the work.

\section{References}

Dieu, B. T. M., Marks, H., Siebenga, J., Goldbach, R., Zuidema, D., Duong, T. P. and Vlak, J. M. 2004. Molecular epidemiology of white spot syndrome virus within Vietnam. J. Gen. Virol., 85: 3607-3618.

Gonzalez-galaviz, J. R., Rodriguez-anaya, L. Z., Molina-garza, Z. J., Ibarra-gamez, J. C. and Galaviz-silva, L. 2013. Genotyping of white spot syndrome virus on wild and farm crustaceans from Sonora, Mexico. Arch. Biol. Sci. Belgr., 65: 945-947.

Hoa, T. T. T., Hodgson, R. A., Oanh, D. T., Phuong, N. T., Preston, N. J. and Walker, P. J. 2005. Genotypic variations in tandem repeat DNA segments between ribonucleotide reductase subunit genes of white spot syndrome virus (WSSV) isolates from Vietnam. Diseases in Asian aquaculture V. Fish Health Section, Asian Fish Society, Manila, p. 339-351.

Hoa, T. T. T., Zwart, M. P., Phuong, N. T., Oanh, D. T. H., de Jong, M. C. M. and Vlak, J. M. 2011. Mixed-genotype 
white spot syndrome virus infections of shrimp are inversely correlated with disease outbreaks in ponds. J. Gen. Virol., 92: 675-680.

Hoa, T. T. T., Zwart, M. P., Phuong, N. T., de Jong, M. C. M. and Vlak, J. M. 2012. Low numbers of repeat units in variable number of tandem repeats (VNTR) regions of white spot syndrome virus are correlated with disease outbreaks. J. Fish Dis., 35: 817-826.

Hossain, M. S., Otta, S. K., Chakraborty, A., Sanath Kumar, H., Karunasagar, I. and Karunasagar, I. 2004. Detection of WSSV in cultured shrimps, captured brooders, shrimp postlarvae and water samples in Bangladesh by PCR using different primers. Aquaculture, 237: 59-71.

John, K. R., George, M. R., Iyappan, T., Thangarani, A. J. and Jeyaseelan, M. J. P. 2010. Indian isolates of white spot syndrome virus exhibit variations in their pathogenicity and genomic tandem repeats. J. Fish Dis., 33: 749-758.

Kalaimani, N., Ravisankar, T., Charavarthy, N., Raja, S., Santiago, T. C. and Ponniah, A. G. 2013. Economic losses due to disease incidences in shrimp farms of India. Fish. Technol., 50: 80-86.

Karunasagar, I., Otta, S. K. and Karunasagar, I. 1997. Histopathological and bacteriological study of white spot syndrome of Penaeus monodon along the west coast of India. Aquaculture, 153: 9-13.

Kiatpathomchai, W., Taweetungtragoon, A., Jittivadhana, K., Wongteerasupaya, C., Boonsaeng, V. and Flegel, T. W. 2005. Target for standard Thai PCR assay identical in 12 white spot syndrome virus (WSSV) types that differ in DNA multiple repeat length. J. Virol. Methods, 130: 79-82.
Musthaq, S. S., Sudhakaran, R., Ahmed, I. V. P., Balasubramanian, G. and Hameed, S. A. S. 2006. Variability in the tandem repetitive DNA sequence of white spot syndrome virus (WSSV) genome and stability of VP28 gene to detect different isolates of WSSV from India. Aquaculture, 256: 34-41.

Otta, S. K., Shubha, G., Joseph, B., Chakraborty,A., Karunasagar, I. and Karunasagar, I. 1999. Polymerase chain reaction (PCR) detection of white spot syndrome virus (WSSV) in cultured and wild crustaceans in India. Dis. Aquat. Org., 38: 67-70.

Pradeep, B., Shekar, M., Gudkovs, N., Karunasagar, I. and Karunasagar, I. 2008. Genotyping of white spot syndrome virus prevalent in shrimp farms of India. Dis. Aquat. Org., 78: 189-198.

Vaseeharan, B., Jayakumar, R. and Ramasamy, P. 2003. PCR based detection of white spot syndrome virus in cultured and captured crustaceans in India. Lett. Appl. Microbiol., 37: 443-447.

Waikhom, G., John, K. R., George, M. R. and Jeyaseelan, M.J.P. 2006. Differential host passaging alters pathogenicity and induces genomic variation in white spot syndrome virus. Aquaculture, 261: 54-63.

Wongteerasupaya, C., Pungchai, P., Withyachumnarnkul, B., Boonsaeng, V., Panyim, S., Flegel, T. W. and Walker, P. J. 2003. High variation in repetitive DNA fragment length for white spot syndrome virus (WSSV) isolates in Thailand. Dis. Aquat. Org., 54: 253-257. 